\title{
Tadeusz Szawiel
}

\section{Socrates: \\ Aretē and Democracy}

DOI: $10.35757 /$ CIV.2009.11.14

\section{Introduction}

The presence of this text among papers that make use of the concept of political theology demands justification. We may reconstruct the meaning of this concept in Carl Schmitt in two ways. First, we may begin with Schmitt's research practice, and in this sense political theology means a study of relations between Christian theology (and especially: Catholic theology) and forms of political organization, together with their doctrinal expression. Schmitt describes these relations with the following notions: analogy, conformity and identity of structures.

Second, we may start with the theoretical self-awareness of Schmitt, who defined political theology in a broader way as "a radical conceptualization, a consistent thinking that is pushed into metaphysics and theology. The metaphysical image that a definite epoch forges of the world has the same structure as what the world immediately understands to be appropriate as a form of its political organization." ${ }^{2}$

Tadeusz Szawiel - Ph.D., vice-director of the Institute of Sociology at the University of Warsaw and the president of the Institute for Study on the Foundations of Democracy. His interests are philosophical foundations of social sciences and problems of contemporary democracies (theories of democracy, civil society, political parties, religiousness and the Church).

1 A modified version of the text from the conference materials: M. Kowalska (ed.): Filozof $w$ polis [A Philosopher in Polis], Wydział Historyczno-Socjologiczny Uniwersytetu w Białymstoku, Białystok 2004.

2 C. Schmitt: Political Theology. Four Chapters on the Concept of Sovereignty, trans. G. Schwab, The University of Chicago Press, Chicago and London 2005, p. 46. 
But there is also a third way, a very radical one, which makes clearly ironic reference to the two presented above. It is represented by Heinrich Meier, an expert and commentator on Schmitt's works, who writes about the two definitions of political theology as follows: "it detoxifies and renders political theology a thesis in the fields of "philosophy of science" or "conceptual history," which is concerned with certain "correspondences," "analogies," or "structural affinities" between theology and jurisprudence." Meier writes that in reality political theology is "a political theory, political doctrine, or a political position for which, on the selfunderstanding of the political theologian, divine revelation is the supreme authority and ultimate ground." 4 This distinguishes political theology from every political philosophy. And it is obvious that what is meant here is Christian Revelation.

The study of the relations between Socrates' arete and the Athenian democracy of the second half of $5^{\text {th }}$ century (here and below always B.C.) cannot be in any way reconciled with the radical understanding of political theology in Meier's interpretation. Nor can it be reconciled with the understanding of theology that is affiliated with Christianity, as the Greek faith was a cult religion, and the Greek mythology, that is, the tales of the gods, is not theology in the sense that this concept has acquired with Christianity. A recently-published extensive volume of essays on political theology assumes this point, as the first texts that it discusses are the Old and the New Testament, followed by essays presenting the viewpoints of St. Augustine and St. Thomas. ${ }^{5}$

In his essay Socrates' Piety of Ignorance, Hans-Georg Gadamer focuses our attention on distinctive differences between Christian and Greek notions in this sphere. ${ }^{6}$ First, he observes that "religion

\footnotetext{
3 H. Meier: What is Political Theology?, in: Heinrich Meier, Leo Strauss and the Theologico-political Problem, trans. Marcus Brainard, Cambridge University Press, Cambridge 2006, p. 78. 4 Ibidem, p. 84.

5 P. Scott, W.T. Cavanagh (eds.): The Blackwell Companion to Political Theology, Blackwell Publishing Ltd., Oxford 2004.

6 H.G. Gadamer: Sokrates Frömmigkeit des Nichtwissens, in: Gesammelte Werke, vol. 7, J.C.B. Mohr (Paul Siebeck), Tübingen 1991. The basic arguments are on pages 83-97.
} 
is not a Greek word, and what the Greek religion really was is something mysterious and strange to every scholar and thinker educated in the Christian West. This is something that cannot be captured with later notions such as theology and metaphysics." However, there did exist Greek equivalents of the notions: "religiousness" or "piety." Here the Greeks used two notions: hosion and eusebeia. Plato uses them interchangeably, though in the course of time hosion is often substituted with eusebeia.

Second, the notions of faith differ. In the New Testament the notion of faith (pistis) refers to something one can rely on, something one can believe in. The Greeks were always distanced from their gods. The notion of faith (pistis) in the New Testament implies a personal attitude toward God, while the Greek notion of pistis in the classical period only means a lower type of knowledge which is backed with credible evidence but is not certain knowledge based on proof.

Third, in the Greek approach to what is divine, man's attitude toward the gods or the inner certainty of faith, according to Gadamer, were not ranked first. The Greeks lived on exteriority, they were convinced that the surrounding reality was animated by the presence of gods. Tales is reported to have said that "everything is filled with gods." To the Greeks, the gods were the ways the world manifested itself, the aspects of reality which was experienced directly in its greatness and power. Proof of this is the word nomidzein (to acknowledge), which describes their attitude toward what is divine. It derives from nomos (law), and thus it refers to what is publicly valid and demands acknowledgment. According to Gadamer, nomidzein is entirely placed in the public sphere: "what is meant here is not the inner certainty of takingfor-granted what is not seen or the intimacy of the personal attitude toward God, but the visible behavior in the public sphere. Nomidzein means first of all taking part in the cult rituals, and

\footnotetext{
7 Ibidem, p. 84.
} 
only secondly acknowledging the existence of the divine which is thus worshipped."

Fourth, the Greeks' religion was not a religion of the book. To the Greeks, poets were theologians, but their theology was not as we understand it. Nomidzein means sustaining and fulfilling the requirements of the cult, which differed depending on polis. The cult was connected with knowledge about the gods but this knowledge was, as Gadamer puts it, "a wild garden of mythical fantasy." Poets took the liberty of interpreting the divine freely, which by no means undermined the religious cults that were binding in the public life. On the contrary, they guaranteed the gods solemn, direct presence and political validity, thus strengthening the religious basis of polis. But such "theology" did not have much in common with the legitimized corpus of the knowledge of God acknowledged as truth.

The problems analyzed in this text fall into the second, broadest understanding of political theology. Its subject is Socrates' attitude toward democracy, and to be more precise, Socrates' relations with the Athenian democracy of the $5^{\text {th }}$ century. A standard viewpoint perceives Socrates as an unyielding critic of democracy, who attacks, derides and despises it. Such is the image of Socrates that Isador Feinstein Stone presents in a simplified form. ${ }^{9}$ While reading Plato's dialogues one may come to the conclusion that democracy was not Socrates' political ideal. But was Socrates rightly perceived by his contemporaries as a misodemos and crypto-oligarch ${ }^{10}$ One may argue - and this is the fundamental thesis of my paper - that Socrates' relations with the Athenian democracy are more complex, and it is this complexity that is a problem. One may claim that, at least in the early dialogues, "Socrates and democracy" create different tensions than in later

\footnotetext{
8 Ibidem, p. 89.

9 I.F. Stone: The Trial of Socrates, Anchor Books, Jacksonville, FL 1989.

${ }^{10}$ G. Vlastos: The Historical Socrates and Athenian Democracy, in: Socratic Studies, Cambridge University Press, Cambridge 1994, p. 87.
} 
dialogues. ${ }^{11}$ And this is the first assumption that this text is based on. The second pertains to the context of culture and political practice in $5^{\text {th }}$-century Athens, and here is where I shall begin.

\section{Socrates' Mission in Athens}

One of the paradoxes concerning Socrates was how he shunned the public life of the polis. It is all the more awkward if we remember that what distinguished an Athenian as a citizen was his political activity. The most important ideal of man in Athens was the ideal of a citizen, that is, someone involved in the matters of polis. Shunning matters of polis meant an Athenian failed as an individual, not in this or that aspect, but failed absolutely, with no chance for compensation.

Let us listen to what Socrates himself says in Apology:

Perhaps it may seem peculiar that I go about in private advising men and busily inquiring, and yet do not enter your Assembly in public to advise the City [symbouleuein te polei] (Apology 31c]. ${ }^{12}$

Socrates, while explaining the cause of this, refers to daimonion (theion te kai daimonion), which - every time it made itself felt - always advised him against doing something, and never advised him to do something:

\footnotetext{
${ }^{11}$ Here I make use of Alexander Nehamas' division of Plato's dialogues into four groups. The earlier dialogues are: Apology, Charmides, Crito, Euthyphro, Hippias Minor, Ion, Laches, and Protagoras. According to Nehamas, the next group of dialogues is connected with the problems raised in the earlier dialogues but it contains certain new solutions: Gorgias, Hippias Major, Lysis, Menexenus, Meno. The middle dialogues in probable chronological order are: Symposium, Phaedo, Republic, Euthydemus, Cratylus, Parmenides, Phaedrus, Theaetetus. the late dialogues in chronological order are: Timaeus, Critias, Sophist, Statesman, Philebus, Laws.

${ }^{12}$ Unless marked otherwise, all citations from the dialogues come from: The Dialogues of Plato, Vol. 1: Euthyphro, Apology, Crito, Meno, Gorgias, Menexenus; Vol. 2: The Symposium, trans. R.E. Allen, Vail-Ballou Press, Binghamton, New York 1984. I have introduced bold letters in some places. Original notions and Greek phrases are given in a simplified form without diacritic marks.
} 
That is what opposed my entering political life, and I think it did well to oppose. For be well assured, Gentlemen of Athens, that had I attempted to enter political affairs, I should long since have been destroyed - to the benefit of neither you nor myself (Apology 31d).

Can Socrates' explanation be accepted as credible? The first thought that comes to mind when we hear the words "had I attempted to enter political affairs, I should long since have been destroyed" is: Socrates is afraid, he fears for his life. But we know perfectly well that Socrates distinguished himself not only through his moral courage, but also through his civil courage. Elaborating on his explanation, he continues:

It is impossible for any man to be spared if he publicly opposes you or any other democratic majority, and prevents many unjust and illegal things from occurring in his city. He who intends to fight for what is just, if he is to be spared even for a little time, must of necessity live a private rather than a public life (Apology 32a).

It is good to contrast Socrates' viewpoint with Pericles' famous statement from the funeral oration: "For, unlike any other nation, regarding him who takes no part in these duties not as unambitious but as useless, we Athenians are able to judge at all events." 13

Socrates' motives may be understood if we take into account several examples from the political practice of Athens. In 428, Mitylene, an ally to Athens, revolted against it. The Athenians sent the hoplites with the strategus Paches, who captured the rebels and sent them to Athens. Thucydides ably describes the violence of Athens toward the captured citizens of Mitylene:

And after deliberating as to what they should do with the former, in the fury of the moment they determined to put to death not only the prisoners at Athens, but the whole adult male population of Mitylene, and to make slaves of the women and children. It was remarked that Mitylene had revolted without being, like the rest, subjected to the empire (The Peloponnesian War, III, 36).

\footnotetext{
${ }^{13}$ Thucydides: The Peloponnesian War, Random House, New York 1982, II, 41. p. 110.
} 
Having passed a resolution the Athenians sent a ship to Paches with an order to execute the sentence immediately. But as Thucydides writes:

The morrow brought repentance with it and reflection on the horrid cruelty of a decree which condemned a whole city to the fate merited only by the guilty (The Peloponnesian War, III, 36).

The assembly was called again and the case was re-examined. Having listened to Cleon (who was for murdering the rebels) and Diodotus (who was against it), the gathering changed the resolution by a slight majority. Another ship was sent to prevent the sentence from being carried out, and it arrived at the last moment. However, this was not the end:

The other party whom Paches had sent off as the prime movers in the rebellion were upon Cleon's motion put to death by the Athenians, the number being rather more than a thousand. The Athenians also demolished the walls of the Mitylenians, and took possession of their ships (The Peloponnesian War, III, 50).

The Hellens were raised on The Iliad and The Odyssey, these were their textbooks and patterns of behavior. Simone Weil called The Iliad "a poem of force" (Le Poème de la Force). One may as well call The Iliad the poem on "the joy of murdering." It is unsurpassed in its amount of splendid descriptions of killing and death, and joy and pride in ingenuity in murdering others. As proof, one may refer to the scene of the death of Hector's charioteer, "the warlike Cebriones," whom "glorious Hector told ... to lash his horses into the fight."

Patroclus on his side leapt from his chariot to the ground with his spear in his left hand. With the other he picked up a jagged, sparkling stone - his hand just covered it - and, refusing to retreat before Hector, threw it with all his force. He did not throw in vain: the sharp stone caught Hector's charioteer Cebriones, famous Priam's illegitimate son, on the forehead, with the horses' reins still in his hands. It shattered both his eyebrows, crushing the bone; and his eyes fell out and rolled 
in the dust at his feet. He fell back out of the well-built chariot like a diver and life left his bones. ${ }^{14}$

One could quote many more great descriptions of how the human body reacts to a spear, stone, sword, arrow, etc. Hellenic culture was permeated with admiration for fighting, killing, conquering, dominating and reigning.

To prove his opinion that "he who intends to fight for what is just" must lead the life of a private man in order to survive, ${ }^{15}$ Socrates refers to two events from the recent past (406 and 404). The first concerns the general accusation laid against ten strategoi (of whom eight were present in Athens) from the victorious naval battle of Arginusae for neither fishing out the shipwrecked soldiers nor burying the bodies of those who had died. The explanation that this was due to a heavy storm was not accepted. The collective accusation was against the law and Socrates, who was then the prytanis, did not agree to it. But the next day, when someone else served as the prytanis, the eight strategoi were sentenced, of whom six present in Athens were executed, among them the son of Pericles and Aspasia. We should add that the battle of Arginusae was the last great victory of Athens before its final defeat. But for Socrates' statement about public life, what followed is more important. Xenophon says that "the Athenians shortly afterwards regretted their death sentence on the generals and proceeded to condemn the accusers and execute them."16 Although Moses I. Finley cautions against drawing rash conclusions from this isolated case, it does render well the possible vicissitudes of life of citizens active during the Assemblies who, no matter how successful they were during the Assembly one day, could meet with the shades in Hades the next day.

\footnotetext{
${ }^{14}$ Homer: The Iliad, trans. E.V. Rieu, Penguin Classics, New York 2003, XVI, 733-743.

15 "Now, do you think I would have lived so many years if I had been in public life and acted in a manner worthy of a good man [andros agathou] [...] Far from it, Gentlemen of Athens. Not I, and not any other man" (Apology 32e).

${ }^{16}$ M.H. Hansen: The Athenian Democracy in the Age of Demosthenes: Structure, Principles, and Ideology, University of Oklahoma Press, Norman, OK 1999, p. 6.
} 
[...] over two or more centuries, Athens had proportionately fewer incompetent generals and political spokesmen then Rome with its self-perpetuating élite and its annual turnover at the highest level, the consuls and praetors [...]. The fact - and I insist that it is a fact - that the Athenian demos displayed so much good discrimination in their selection of leaders, by vote in the case of the strategoi or by their support for individual policy-makers in the Assembly, cannot be explained by apathy, the favorite concept of our élitist school of political scientists. Apathy cannot be attributed to the many thousands who attended Assembly meetings with some frequency, who served on the Council once or twice, and who made up the jury-courts, again in the thousands. The only alternative, it seems to me, is to think of widespread civic responsibility, a moral attribute that historians seem to shy away from, understandably in part (but only in part) because of its evident subjectivity as a category and the difficulty in demonstrating its presence. It is so much easier to seize on a few instances of seemingly irresponsible behavior, such as the execution on instruction of the Assembly of the generals who had commanded the victorious Athenian fleet at Arginusae in 406 B.C., as ground for condemnation the system as a whole. ${ }^{17}$

Thus, according to Socrates, he does not deal with politics. However, he is not a private person. He thus speaks about his significance for Athens:

For the God commands this, be well assured, and I believe that you have yet to gain in this City a greater good [meidzon agathon genesthai en te polei] than my service to the God. I go about doing nothing but persuading you, young and old, to care not for body or money, in place of, or so much as, excellence of soul (Apology 30a).

And he explains what does this service to the God mean:

That I am just that, a gift from the God to the City, you may recognize from this: It scarcely seems a human matter merely, that I should take no thought for anything of my own, endure the neglect of my house and its affairs for these long years now, and ever attend to yours, going to each of you in private like a father or elder brother, persuading you to care for virtue [aretē] (Apology, 31b).

\footnotetext{
${ }_{17}$ M.I. Finley: Politics In the Ancient World, Cambridge University Press, Cambridge 2002, p. 140.
} 
Here came a question that Socrates himself formulates: Why does he "go about in private advising men" with such commitment, believing that this is his destiny, and does not appear in an open forum, does not advise polis? ${ }^{18}$ We know that it is daimonion that forbids him to deal with politics, and Socrates explains this prohibition as useful to him, as otherwise he would pay with his life for his public involvement. But there is a different explanation for this strategy. Walter Bröcker formulates a very interesting argument. If all the country (polis) is spoilt - and in Apology and Gorgias Socrates brings forth arguments proving this thesis - then healing must start with individuals, with making citizens better, as addressing the whole polis during the Assembly may cost one his life. ${ }^{19}$ In Gorgias this "making citizens better" is a measure according to which Socrates judges politicians. And the greatest Athenian politicians (Pericles, Cimon, Miltiades, Themistocles) turn out to be poor politicians by this measure. ${ }^{20}$ It should be underscored that Socrates does not question their greatness in the common sense. To Callicles' claim that none of the contemporary politicians could equal them in deeds, Socrates responds:

Dear friend, I'm not blaming them either, at least as servants of the city. On the contrary, they seem to me to have been more serviceable than those now and better able to provide what the city desired. But as for changing those desires and not giving in to them, as for persuading and compelling to that through which the citizens will become better - they were scarcely any different (Gorgias 517 bc).

The key word that appears here is obviously servants (diakonoi). Callicles' mistake is confusing a great politician with a servant. Socrates perceives all the great Athenian politicians that Callicles

\footnotetext{
18 "I go about in private advising men and busily inquiring, and yet do not enter your Assembly in public to advise the City" (Apology, 31c).

${ }^{19}$ Walter Bröcker: Platos Gespräche, Vittorio Klostermann, Frankfurt am Main 1985, p. 24.

20 "Are the Athenians said to have become better due to Pericles, or, quite the contrary, to have been corrupted by him? For I do hear that. I hear that Pericles made the Athenians lazy, avaricious, talkative, and cowardly by first instituting the system of public pay" (Gorgias $515 \mathrm{e})$.
} 
enumerates as servants ("You tell me about servants who cater to desires, without realizing there is nothing fine or good about them," Gorgias 518c) and considers them as the creators of the polis's corruption. ${ }^{21}$

Now we better understand Socrates' mission in Athens: the calling to be a better citizen.

[...] I undertook to persuade each of you not to care for anything which belongs to you before first caring for yourselves, so as to be as good and wise as possible, nor to care for anything which belongs to the City before caring for the City itself [prin heatou epimelethein hopos hos beltistos kai phronimotatos esoito, mete ton tes poleos, prin autes tes poleos] and so too with everything else in a similar way (Apology 36c).

That is why Socrates thinks that his activity is the greatest good in the polis. Not a light statement; but nor is it the strongest, as he also goes on to say:

I think that I am one of the few Athenians, and I say few in order that I may not say only, who undertakes to practice the true art of politics, and that I alone among our contemporaries perform the statesman's task (Gorgias 521d).

How are we to understand this? Socrates is the only one ready for the "struggles with the Athenians so that they will be as good as possible" (Gorgias 521a). He understands this "struggle" in a specific way: "going to each of you in private like a father or elder brother, persuading you to care for virtue [aretē]" (Apology $31 \mathrm{~b})$. Socrates is the only one who performs politics, as he is the only one who endeavors to make the Athenians better men. His political activity (prattein ta politika) is true politics because it focuses on what is most important, on the Athenians' arete, and not providing goods to polis and satisfying the needs (Socrates will say "desires") of the citizens. He thinks that rendering services

\footnotetext{
21 "You're praising the men who fed and feasted the citizens on what they desired. People say those men of earlier times made the city great. They are unaware that its greatness, due to them, is that of a tumor, scabbed over and festering" (Gorgias 518e).
} 
to the polis does not make sense ("They have filled the city with harbors and dockyards and walls and tribute and other such nonsense without justice and temperance" Gorgias 519a) when the citizens are bad citizens; if they are, for instance, unjust. As then evil prevails in the country (spoilt polis, not observing the law) and in such a polis "in this city anything can happen to anybody," everyone may be prosecuted "by a wicked man" (Gorgias 521c).

Who then is Socrates in the polis? When he goes out in the morning and heads for the gymnasion, then he is not going as someone who has prepared a lecture, speech or trained strategy of arguing like a sophist in advance. Depending on whom he meets, on the circumstances and opportunities, his activity is always an event - something happens to him and the others. In this sense the Athenian polis is the condition that makes Socrates' mode of being possible.

But the essence of this democratic polis is tragic: avaricious, hungry for glory, power, and blood, committed to informing, conceited and dogmatic citizens are the condition that makes Athens's whole grandeur possible, as well as everything that survived out of this less than two hundred years (508-322) and still exists. Socrates never said so, but his behavior - not leaving the polis, remaining at his post, observing the laws (Criton) - proves that he appreciated this somehow. It seems that the Socrates of the early dialogues understood that there could not be a significantly better polis, in the sense of a polis with a significantly better constitution. ${ }^{22} \mathrm{He}$ was interested in the

\footnotetext{
${ }^{22}$ Thus Gregory Vlastos (op. cit., p. 91) interprets the speech from Crito: "So eagerly did you choose us, so eagerly did you agree to live as a citizen under us, that you even founded a family here. So much did the City please you." (52c) and "But you preferred neither Sparta nor Crete, which you often used to say were well governed, or any other city, Greek or barbarian." (52e-53a) Vlastos points to the fact that what distinguished Athens was a democratic constitution. Both Sparta and Crete were radical oligarchies. Adam Krokiewicz's remark is also important: "As Socrates did not distinguish a law-observing democracy and a law-unobserving democracy, one may suppose that he considered it to be the best political system, theoretically." In: A. Krokiewicz: Socrates, Etyka Demokryta i hedonizm Arystypa [Socrates, Democritus' Ethics and Aristippus' Hedonism], Fundacja Aletheia, Warszawa 2000 , p. 82.
} 
citizen as he is here and now. He always emphasized that he did not teach his fellow citizens, but only checked whether they had knowledge about aretē.

For the Athenians, a man was a citizen, but not in the contemporary sense. They were interested not in man as he is, but in man as a politically active citizen. An Athenian was an element of the polis when he contributed to its good, in the sense that Pericles and others - whom Socrates criticized for being servants and not good politicians - contributed to the good of Athens. They were not concerned with a useless citizen as a man (executing the strategoi, accusing and killing Fidias). Socrates saw man in a citizen. For him a man was also first a citizen, but something more as well: he had a soul for which he cared.

\section{Socrates Is from Somewhere}

Socrates is from somewhere, his origin is irremovable. He himself does not imagine a different site for his service, nor is understanding Socrates possible outside the context of $5^{\text {th }}$-century Athens. However, it is Socrates who is known from Alcibiades' description as atopos. These two facts do not exclude each other; what is more, the condition that makes Socrates' being atopos possible is his being in Athens. Pierre Hadot says that "Socrates is the first individual in the history of Western thought" due to his originality, uniqueness and incomparability. In this sense Socrates is atopos. "Ethymologically, atopos means "out of place," hence strange, extravagant, absurd, unclassifiable, and disconcerting." ${ }^{23}$

Let us look closer at what Alcibiades highlights in his praise of Socrates in Symposium:

${ }^{23}$ P. Hadot: Philosophy as a Way of Life. Spiritual Exercises from Socrates to Foucault, trans. M. Chase, Blackwell Publishing, Malden, MA 2003, p. 158. 
Unlikeness to any other man, past or present, is worthy of all wonder. One might compare the sort of man Achilles was to Brasidas and others, and Pericles, again, to Nestor and Antenor, and there are others one might compare in the same way. But the sort of man this is and his strangeness [hoios de houotsi gegone ten atopian anthropos], both himself and his words, one couldn't come close to finding if one looked, neither among people present nor past, except perhaps if one were to compare him to those I mention - not any man, but silenes and satyrs, him and his words. (Symposium 221cd)

Pierre Hadot explains this in detail:

It is in Alcibiades' speech in praise of Socrates that the representation of the Individual appears, perhaps for the first time in history. This is the Individual dear to Kierkegaard - the Individual as unique and unclassifiable personality. [...] Socrates, in contrast, is impossible to classify; he cannot be compared with any other man. At most, he could be compared with Silenoi or Satyrs. He is atopos, meaning strange, extravagant, absurd, unclassifiable, disturbing. In the Theaetetus, Socrates says of himself: "I am utterly disturbing [atopos], and I create only perplexity [aporia]." 24

But Hadot focuses our attention on yet another aspect of Socrates' atopia: "What makes him atopos is precisely the fact that he is a 'philo-sopher' in the ethymological sense of the word: that is, he is in love with wisdom. For wisdom, says Diotima in Plato's Symposium, is not a human state, it is a state of perfection of being and knowledge that can only be divine. It is the love of this wisdom, which is foreign to the world, that makes the philosopher a stranger in it." 25

But atopia, this unclassifiability, this surpassing every category does not contradict the concept that he is from somewhere, that he is located. In Apology there is an extremely important confession:

I think it might be appropriate to say, "I too have relatives, my friend; for as Homer puts it, I am not 'of oak and rock', but born of man, so I have relatives - yes, and sons, too Gentlemen of Athens, three of

\footnotetext{
${ }^{24}$ P. Hadot: What is Ancient Philosophy? trans. M. Chase, Harvard University Press, Cambridge, MA 2004, p. 30.

${ }^{25}$ P. Hadot: Philosophy..., p. 57.
} 
them, one already a lad and two of them children. Yet not one of them have I caused to come forward here, and I shall not beg you to acquit me (Apology, 34d).

Socrates differs from his contemporary philosophers in the fact that he is from somewhere not only in the sense of place of birth (e.g.: Gorgias of Leontini): "I too have relatives [...] I am not of oak and tree, but born of man, so I have relatives - yes, and sons, too [...]" (Apology) These words sound extraordinary, as in the dialogues we never see Socrates with his family, sons - except for the mention in Phaedo (116b) that he meets with the children and women from his home. However, this remains unseen by both the narrator and us, as it occurs in the neighboring room. These words of Socrates': "I too have relatives, sons" point to his rootedness, they refer back to the initial place for a man: to his origin and location. These Socratic statements have strength that does not depend on their function and meaning in Apology. Truly, Socrates does quote them with a certain purpose, but their meaning exceeds the motive for quoting them. The quotation from Homer's Odyssey, which Socrates used, and which is specific, proves it. These are not Homer's words, nor his protagonists', but an interjection. Penelope - who speaks them - uses a citation. She turns to Odysseus, whom she does not recognize:

Tell me who you are, and the place where you come from. You were not born from any fabulous oak, nor a boulder. ${ }^{26}$

The fact that Socrates quotes a citation adds significance to this utterance. It must have been exceptional to him. It refers to ties that are important to him. ${ }^{27}$

\footnotetext{
${ }^{26}$ Homer: The Odyssey, trans. R. Lattimore, HarperCollins Publishers, New York 1999, p. 286. ${ }^{27}$ Hadot's following remark may be interpreted as pointing to Socrates' location: "On the other hand, the portrait of Socrates as sketched by Alcibiades in Plato's Symposium - and also by Xenophon - reveals a man who participated fully in the life of the city around him. This Socrates was almost an ordinary or everyday man: he had a wife and children, and he talked with everybody - in the streets, in the shops, in the gymnasiums. He was also a bon vivant who could drink more than anyone else without getting drunk, and a brave, tough soldier" (P. Hadot: What is Ancient..., p. 37).
} 
The second testimony to Socrates' rootedness is his notion of "remaining at the post":

Wherever a man stations himself in belief that it is best, wherever he is stationed by his commander, there he must I think remain and run the risks, giving thought to neither death nor any other thing except disgrace (Apology 28d).

Socrates discerns a distinctive parallel between his submitting to the leaders and submitting to god. He says:

When the commanders you chose stationed me at Potidaea and Amphipolis and Delium, I there remained as others did and ran the risk of death; I should indeed have wrought a fearful thing, Gentlemen of Athens, if then, when the God stationed me, as I thought and believed, obliging me to live in the pursuit of wisdom, examining myself and others - if then, at that point through fear of death or any other thing, I left my post (Apology, 28de).

The third testimony is his defending the country: for the first time at Potidaea (432/430), where he saves the life of Alcibiades and shows extreme resistance to adversities (the cold, difficult conditions of camp life). Then he took part in the battle at Delium, where he exhibited courage during the retreat (he was with Laches), a fact to which Alcibiades pointed. And finally, he fought at Amphipolis in 422, where Thucydides commanded and where Cleon (Athens) and Brasidas (Sparta) lost their lives. He put himself at risk many times for Athens, he displayed courage and did not fear death, and it is worth recalling that during the battle of Amphipolis he was almost 50 years old.

\section{Socrates and Democracy}

Socrates never criticizes the constitutional foundations of the Athenian polis, nor does he criticize politicians chosen by demos for their concrete actions. He only states that they do not know 
what they are certain they know. He doubts whether Themistocles and Pericles have knowledge of aretēe. ${ }^{28} \mathrm{He}$ does not criticize the catastrophic events which contributed to Athens's decline. He never speaks about the Peloponnesian War, though we know that from 432 (Potidaea) to 422 (Amphipolis) he took part in military campaigns three times as a hoplite. He never mentions Mitylene (428) or the murder of the citizens of Melos (416) for which if we are to believe Plutarch - Alcibiades was responsible. ${ }^{29}$ In Symposium when drunken Alcibiades enters the house of Agathon, it is the same Alcibiades who just contributed to murdering all the citizens of Melos - or who will contribute to it in a while. Finally, he never mentions the catastrophic Sicilian expedition (415-413), in which twelve thousand Athenian citizens (that is, one third of the total) lost their lives, 12 strategoi (among them Nicias) were executed, and Athens was humiliated. ${ }^{30}$ We do not know how Socrates reacted to this, but we may conjecture. We know that at the moment of his death Socrates had a teenage son and two little sons. Perhaps Socrates' reaction, as a citizen, to the defeat was to start a family (he was 55-57) thus - by providing new citizens - showing loyalty to Athens. In this sense Socrates fulfilled his civic duty. And for the lack of objection (or maybe

\footnotetext{
28 "So it is not by a kind of wisdom [sophia] or because they are wise that men such as Themistocles, and those like him whom Anytus here just mentioned, guide their cities. For they cannot make others like themselves, since they are not what they are because of knowledge" (Meno 99b).

${ }^{29}$ Alcibiades lived from ca. 450 B.C to 404 B.C. Plutarch writes: "[...] he picked out a woman from among the prisoners of Melos to be his mistress, and reared a son she bore him. This was an instance of what they called his kindness of heart, but the execution of all the grown men Melos was chiefly due to him, since he supported the decree therefore [the decree of the Assembly to put to death all the grown men from Melos - T.S.]. I quote after the English version of the description of Alcibiades' life by Plutarch (http://www.perseus.tufts.edu).

30 "During two years Athens were irreversibly defeated at the besieged Syracuse which bravely defended itself with the Spartans' aid. The terrible defeat at the Assinarus river (413) entailed the loss of all soldiers who took part in the expedition, the dead and the sentenced to a slow death in the gloomy dungeons of Syracuse [in quarries - Thucydides]. Twelve Athenian commanders, among them Nicias, were put to death and 12,000 citizens died, which led to the ultimate decrease of Athens' human potential." P. Leveque: Świat grecki [The Greek Adventure: A Cultural and Historical Study of the Ancient Greeks] trans. J. Olkiewicz, Państwowe Wydawnictwo Naukowe, Warszawa 1973, p. 267.
} 
even absence) during ecclesia that made a decision to help Segesta and the whole gigantic expedition to Sicily in 415, Gregory Vlastos reproaches him. ${ }^{31}$

The Athenian polis was Socrates' condition of possibility, and not only in the sense that only in Athens could someone like Socrates appear. We can say more: his mission was only possible in a polis such as Athens.

Athenian democracy of the $5^{\text {th }}$ century was a great institutional achievement which was developed through decades. Its institutional framework was created by Athenian citizens (o andres Athenaioi, as Socrates calls them); those greedy, cunning, dull Athenians. They created the idea of the rule of all, the Assembly, appointing strategoi by a vote, courts, and sophisticated procedures of appointing officials and controlling them (ostracism, graphe paranomon). This institutional framework enabled easy communication and freedom of speech (parrhesia - the opportunity to say everything - including difficult things - to the whole polis and the ruler) ${ }^{32}$ making every citizen's opinion of the same value. It gave a chance to argumentation, not power; it favored high self-esteem and spontaneous curiosity. It created chances for every citizen as the majority of posts were filled by a vote, and theoretically everyone could be chosen as a strategos. This institutional framework, together with beliefs, customs and social structure, created a special form of life. Neither Socrates nor any individual reformer created this form of life. It was the outcome of the work of generations, it required enormous self-discipline: every day, out of six thousand Athenians chosen as judges for a given year (from all Athenians over thirty years of age) from 1,500 to 2,000 took part, 175-220 days per year, as members of the jury in lawsuits (in ten tribunals). In no country nowadays could this

\footnotetext{
${ }^{31}$ G. Vlastos: Socratic Studies, Cambridge University Press, Cambridge 1994, pp. 128-129. 32 According to Alexander Nehamas, who refers to Michel Foucault, it was Socrates who expanded parrhesia into relations between individuals. Cf. A. Nehamas: The Art of Living. Socratic Reflections from Plato to Foucault, University of California Press, Berkeley 2000, pp. 164-166.
} 
be possible. The cost of the courts' work per year was 22-37 talents $(444,000$ daily rates, for a whole day service each juror got 3 obols, that is half a drachma; average worker's daily wage was 1.5-2.5 drachmas, that is, 9-15 obols). If we assume that working days for courts were around 200 per year (there could be 225 such days at most, due to holidays), then every day there were 2,220 jurors who judged in dicasteries. ${ }^{33}$

It is enough to recall Plato's life at the court of Dionysius in Syracuse to make evident the difference that distinguished Athens from many other poleis. Only in Athens could Socrates meet, every morning on his way to the town, Cleinias (Euthydemus) or Phaedrus (Phaedrus). Only in Athens could he be Socrates. Who are you, Socrates? What answer could we hear? An Athenian who each day sets off to meet living aretē. Every such expedition is not yet another exercise in elenchus, but creates an event: a gesture of life. And this, Socrates' basic gesture of life, is kindness for every Athenian as an individual.

But democracy as a way of living also had its dark side: it was based on greedy, superstitious, vengeful citizens. Courts in Athens many times sentenced its citizens to death in - as we would say nowadays - political cases. However, this punishment was usually evaded either by fleeing from Athens beforehand or escaping the sentence pronounced. Socrates was the first toward whom the most radical, ultimate possibility of this form of life was carried out. Socrates' death was, in a way, its fulfillment, as "Those who come to examine you will be more numerous" (Apology 39d). His mission would be continued because it was inscribed in this form of life. That is why Socrates accepted his death as something good:

I will tell you. Very likely what has fallen to me is good, and those among us who think that death is an evil are wrong. There has been convincing indication of this. For the accustomed Sign would surely have opposed me, if I were not in some way acting for good (Apology, 40bc).

\footnotetext{
${ }^{33}$ M.H. Hansen: The Athenian Democracy..., pp. 181-189.
} 
However, he is not entirely sure:

But it is now the hour of parting - I to die and you to live. Which of us goes to the better is unclear to all but the God (Apology 42a).

\section{Knowledge and Aretē}

However, is Socrates capable of fulfilling his mission as the only one "who undertakes to practice the true art of politics, and [...] performs the statesman's task [prattein ta politika]"? Is he capable of "improving" the Athenians, that is, convincing them to live in accordance with aretai? Let us leave aside the answer to the question whether Socrates managed to "improve" the Athenians with whom he talked, and who could pass for his apprentices. William K. Guthrie thinks that he did, referring to Socrates' words during his conversation with Theaetetus. And even if Theaetetus conceives nothing, then "he will be a better man for the knowledge of his own ignorance." 34

But what is aretê? Pierre Hadot gives a good explanation to this question while referring to Xenophon, in whose The Memorabilia ${ }^{35}$ Hippias turns to Socrates:

We have had enough of your ridiculing all the rest of the world, questioning and cross-examining first one and then the other, but never a bit will you render an account to any one yourself or state a plain opinion upon a single topic (The Memorabilia, IV, 18).

Socrates replies:

If I fail to proclaim it [what he regards as just and upright] in words, at any rate I do so in deed and in fact (The Memorabilia, IV, 19).

\footnotetext{
${ }^{34}$ W.K.C. Guthrie: Socrates, Cambridge University Press, Cambridge 2000, p. 125. Socrates: "Well then, if you try, later on, to conceive anything else, and do so, what you're pregnant with will be the better for our present investigation. And if you stay barren, you'll be less burdensome to those who associate with you, and gentler, because you'll have the sense not to think you know things which in fact you don't know. That much my art can do, but no more..." (Theaetetus, trans. J. McDowell, Oxford University Press, Oxford 1999 (210bc).

${ }^{35}$ Xenophon: The Memorabilia (e-text version).
} 
This means, "in the last analysis, that it is the just person's life and existence which best determine what justice is." 36

Hadot underscores many times that this knowledge of "how to be just," or "how to be wise" is not an object-like knowledge. Socrates, trying to answer what the oracle's response means, "began a long search among politicians, poets, and artisans - people who, according to the Greek tradition [...] possessed wisdom or knowhow [italics mine - T.S.]." 37

If the question concerns the knowledge of knowhow (i.e. how to act), then it means that this is the question about adequate, good behavior.

Hadot emphasizes this even more:

This means that knowledge is not a prefabricated object, or a finished content which can be directly transmitted by writing or by just any discourse. ... Socrates' questions do not lead his interlocutor to know something, or to wind up with conclusions which could be formulated in the form of propositions on a given subject. ... Here again, knowledge is not a series of propositions or an abstract theory, but the certainty of choice, decision, and initiative. Knowledge is not just plain knowing, but knowing-what-ought-to-be-preferred, and hence knowing how to live [italics mine - T.S.]. ${ }^{38}$

What kind of knowledge did Socrates not have? He was right in saying that he does not have the knowledge of arete which would be the basis for a good life, as such knowledge is of another kind: it is a practical knowledge. Socrates was not wrong when he said that he did not have knowledge. He was wrong if he thought one could possess this knowledge. It is true: Socrates wanted to learn from others, he stated that arete is knowledge. On the other hand, did he not know that there is no such knowledge? Did god not use him as a tool to show that "man's wisdom is worth little or nothing" and that object-like knowledge of the good life (aretai)

\footnotetext{
${ }^{36}$ P. Hadot: What is Ancient..., p. 31.

${ }^{37}$ Ibidem, p. 25.

${ }^{38}$ Ibidem, pp. 26-33.
} 
is worth nothing. The god was right: the only knowledge man can have about this issue is knowing that we do not have this knowledge. In no early dialogue is the object-like knowledge on the good life (life in accordance with aretai) successfully formulated: they all end in aporia.

Walter Bröcker remarks that "the point is not that people cannot know anything; people do not have the knowledge on how to attain good [das Gute zu gewinnen]. The knowledge that people cannot possess is the knowledge one should have if pedagogy were possible. This is the knowledge on what is decisive for man, that is, what is good for him. The good [to agathon] is something that man does not know and cannot know, though the sophists claim they do." 39

As Bröcker notes, Socratic "knowledge of ignorance" is not about "what is good and what is bad from the moral perspective: Socrates knows what he can and cannot do, or what he ought to do; he is entirely aware of it and has no doubts (he knows he should not escape)." ${ }^{\prime 0}$

But this does not mean that a good life (to eu dzen i eudaimonia) is impossible and that there is some secret: no, there is no secret. Socrates is a practitioner of the good life and has knowledge, but it is a practical knowledge which will be theoretically developed by Aristotle in Nicomachean Ethics. ${ }^{41}$ Practical knowledge (phronesis) is knowledge in a situation, it is as primordial as the situation of action. It cannot be an object-like knowledge as, necessarily, we cannot have knowledge of what is going to happen, and action (praxis) is always before us. Practical knowledge is not something you can have, just as an artisan has knowledge of how to build a house or a ship. That is why Socrates so consistently and tenaciously clings to his opinion that there is no knowledge of

\footnotetext{
${ }^{39}$ W. Bröcker: Platos..., pp. 15-16.

40 Ibidem, p. 17.

${ }^{41}$ It is stressed by Hans-Georg Gadamer in his study Die Idee des Guten zwischen Plato und Aristoteles, in: Gesammelte Werke, Bd. 7, J.C.B. Mohr (Paul Siebeck), Tübingen 1991, p. 146.
} 
arete, of the good life. Socrates does not have a theory of practical knowledge; he is, so to speak, a practitioner of practical knowledge and, perhaps, has an intuition that the knowledge he searches for in every person is not a possible object of cognition. Thus it is not knowledge that one can teach, as it is impossible to teach someone what will happen. Aretē cannot be taught also for another reason. The situation of action is a situation of application (for example, applying a norm to a concrete, individual and unique situation), it is a creative achievement, as there are no rules for its application (otherwise we risk regression). Being creative cannot be taught. And that is why Menon ends negatively - aretē cannot be taught.

Interpreting "the knowledge of ignorance" as practical knowledge has its merits. It enables us to understand phenomena that exceed other interpretative patterns. The first is the Socratic daimonion. Daimonion is not a private oracle, as Kierkegaard wants it to be. The oracle's answers always required explanation; we know how much trouble Socrates had understanding what the oracle said in his case. On the other hand, daimonion's voice was always direct, never requiring any interpretation.

Let us quote excerpts from the dialogues in which Socrates refers to his daimonion:

My accustomed oracle, which is divine, always came quite frequently before in everything, opposing me even in trivial matters, if I was about to err [me orthos praxein] (Apology 40b).

... But the Sign of the God did not oppose me early this morning when I left my house, or when I came up here to the courtroom, or at any point in my argument in anything I was about to say. And yet frequently in other arguments it has checked me right in the middle of speaking; but today it has not opposed me in any way, in none of my deeds, in none of my words (Apology 40b).

Very likely what has fallen to me is good, and those among us who think that death is an evil are wrong. There has been convincing indication of this. For the accustomed Sign would surely have opposed me, if I were in some way acting for good [ei me ti emellon ego agathon praxein] (Apology 40bc). 
My friend, just as I was about to cross the river, the familiar divine sign came to me which, whenever it occurs, holds me back from something I am about to do [prattein]. I thought I heard a voice coming from this very spot, forbidding me to leave until I made atonement for some offense against the gods [...] that's why, almost from the beginning of my speech, I was disturbed by a very uneasy feeling, as Ibycus puts it, that "for offending the gods I am honored by men" But now I understand exactly what my offense has been [to hamrthema]. ${ }^{42}$

The divine voice always appears in the context of action, and always "if [Socrates] were not in some way acting for good." Socrates' daimonion is a form of phronesis - Aristotelian practical knowledge, it is a way phronesis expresses itself in action. Socrates has daimonion: Socrates possesses prohairesis, the ability to put something above something else. Although daimionion always stops him, in fact it has a positive meaning: it stops the negative character of life - by choosing one way of acting one excludes the other possibilities (Heidegger). Thus Socrates' daimonion opens the horizon for good actions - eupraxia.

But not only daimonion can be interpreted within this paradigm; theia moira can as well (göttliche Zugebung; a gift from the gods). In the last parts of Menon Socrates gives a surprising answer to a question about the source of arete in those who undoubtedly manifest it. Since the previous argumentation led to the conclusion that "we have arete neither from nature, nor from instruction," then those who have it possess it thanks to theia moira. ${ }^{43}$

Walter Bröcker remarks in his Platos Gespräche (while commenting on the last parts of Meno):

\footnotetext{
${ }^{42}$ Plato: Phaedrus, trans. A. Nehamas, P. Woodruff, Hackett Publishing Company, Indianapolis $1995,242 \mathrm{~cd}$.

43 "For the time being, however, if our enquiry has gone well, and we've been right in what we've been saying throughout our discussion, excellence [aretē] cannot be a natural [physei] endowment and cannot be teachable [didakton] either. No, the excellence of good people comes to them as a dispensation awarded by the gods [theia moira], without any knowledge - short of there being a politician with the ability to make someone else an expert politician too." (Meno 99e). Later (100b) in the dialogue, Socrates speaks thus about theia moira: "So, Meno, our argument has led us to suppose that the excellence of good people comes to them as a dispensation awarded by the gods [theia moira]." Plato: Meno and Other Dialogues, trans. R. Waterfield, Oxford University Press, Oxford 2005.
} 
What appeared here is that excellence is neither a natural endowment nor can it be taught: we possess it as a dispensation awarded by the gods. Thus we again approach Socrates' standpoint from Apology: it is not only the question of the knowledge of ignorance but also of knowing that it is impossible to possess knowledge which - due to the impossibility to overcome ignorance - must allow the divine sign to tell it what is decisive. The dispensation awarded by the gods that Plato speaks about and daimonion in Apology are substantially the same. ${ }^{44}$

How do people have aretēe Neither from nature, nor instruction, but Bröcker notices that in Meno Socrates states something more; not only the knowledge of ignorance, but the knowledge of the impossibility to possess knowledge (Nichtwissenkönnens). Because of the impossibility of overcoming ignorance, only god may say what is essential.

The interpretation of "knowledge" - thanks to which Socrates is the master of eupraxia and leads a good life - as phronesis enables us to understand why he cannot convince others, such as Alcibiades. Instruction and argumentation (also daimonion and theia moira) can say something to a person only if he/she is already someone. In order to hear the voice of god (in fact, any calling), one needs to be someone. Logos (an argument) and theos (god) must rely on what there already is (Aristotelian to hoti). This also enables us to understand why god prohibits Socrates from spending time with those who had earlier left him:

Many of them in their ignorance, either in their self-conceit despising me, or falling under the influence of others, have gone away too soon [...] The truants often return to me, and beg that I would consort with them again - they are ready to go to me on their knees and then, if my familiar allows, which is not always the case, I receive them, and they begin to grow again. ${ }^{45}$

An analogy with Aristotle's well-known statement from Nicomachean Ethics comes to mind here: "That is why we need to have been

\footnotetext{
${ }^{44}$ W.Bröcker: Platos..., p. 120.

${ }^{45}$ Plato: Theaetetus, trans. S.W. Dyde, Forgotten Books, New York 1899, pp. 16-17.
} 
brought up in fine habits if we are to be adequate students of fine and just things, and of political questions generally. For we begin \{arche\} from the [belief] that \{to hoti\} [something is true]." ${ }^{\prime 46}$

When they are already someone - and here it means that they are sensitive to his "arguments" - maieutics may take place. Only then may they discover ("conceive") something within themselves that Socrates will help to bring to life.

Socrates cannot be a teacher because he knows that he does not know anything. But also, in his role of maieutic he is radically limited: "if my familiar allows, which is not always the case."

Here we come to the question about the limits of making the art of the good life universal: Why is it only Socrates who hears the voice of daimonion? Socrates responds to this question in Xenophon. Daimonion must rely on what there is (Aristotle: arche gar to hoti), which is well rendered by Walter Bröcker:

But why does Socrates alone have such an advisor? Anyone may receive such an advice if he asks for it. That only Socrates has daimonion comes from the fact that he is the wisest: he is the only one who knows that he does not know the good and cannot know it on his own. This knowledge of ignorance is the condition of possibility of hearing the divine advice. The one who is certain that he knows what is good for him cannot hear the advice of the divine voice. On the other hand, how is the one (aware that he does not and cannot know what is decisive, that is, good for him) supposed to live, that is make choices again and again - if what he cannot reach by himself was not to be said to him? Daimonion is the response to the knowledge of ignorance. ${ }^{47}$

From this point of view it seems that Alexander Nehamas is wrong when he says that:

Socrates seems certain that his way of life - the examined life of the Apology (38a5-6) - is the best life for all human beings. But he has no argument to convince those who disagree with him or who simply don't care. He has nothing to say to Euthyphro to make him stay when the latter walks away from their conversation (15e3-16e3). ${ }^{48}$

\footnotetext{
${ }^{46}$ Aristotle: Nicomachean Ethics, trans. T. Irwin, Hackett Publishing Company, 1999, 1095b 6.

${ }^{47}$ W. Bröcker: Platos..., pp. 25-26.

${ }^{48}$ A. Nehamas: The Art of Living..., p. 96.
} 
This is not a question of argumentation - Nehamas overestimates its capabilities. To recognize an argument as an argument - not to speak of recognizing its content - one needs to be someone, and this is something over which Socrates has no power (no one does). Socrates will not stop Euthyphro, not because he does not have an argument - even if he had one, it would be of little avail. To recognize Socrates' "argument," Euthyphro would have to be someone else, and this is something beyond Socrates' and anybody else's - capabilities. Here is the source of sorrow and regret sometimes felt in the dialogues. Euthyphro leaves and Socrates cannot stop him. But this does not mean that the transformation of the soul is impossible. This transformation may occur, though does not have to, and - importantly - this is not an object of any formal strategy, any knowledge which could bring about the transformation. Socrates' interlocutors often complain that he always repeats the same, asks the same questions, is tireless in beginning anew. Patient trials and waiting is the only conscious strategy that may bear fruit. Socrates is patient, he will spend his life waiting for his opportunity: the moment when the scales fall from his interlocutors' eyes and they discern. What will they discern? Everyone up to his own standards. Alcibiades will perceive that he is not capable of meeting the requirements that being with Socrates imposes.

Life is always ahead of us. An argument is the tip of the iceberg. It is a true miracle that sometimes an argument moves the iceberg. It was Socrates' wisdom that he knew this. The most beautiful and the most optimistic scenes are the farewells. Until the next conversation. Every morning Socrates set off on his duty given to him by god, at his post. And he persevered at this post to the very end. And he unshakably believed that it was righteous. Was he right? If he had not been, we would not be here.

Since Socrates cannot be sure whether he will succeed, if he succeeds he can only give thanks to god. This is how Socrates' maieutics may be understood: whether someone bears a thought 
is not Socrates' work. Much like a child that a woman bears is not the midwife's work. What is possibly borne is irreducibly autonomous: it is independent (Socrates may fail) and "manages itself" (like a fetus that develops in a womb according to its own "logic" is an event which can be controlled neither by the woman who gives birth to it, nor by a midwife).

Democracy is a form of life. When a question arises: What does democracy give? one may answer: it gives nothing. Democracy is not a tool, more or less imperfect. It is the way that large societies and individuals who shape them live, the way which may be perceived as worthless. Every aspect of democracy may be ridiculed or derided.

Where does the attractiveness of democracy - increasingly widespread since the 1970s - come from? To a great extent, from its instrumental advantages, often underestimated. Until recently it was thought that authoritarian regimes contribute to economic growth and welfare more than any democratic system of rule. Democracy as a form of life is achieved by constant work on life, in the sense that Socrates was a worker in Athens: he was such a worker in the field of life. But this work may have an effect similar to that of Socrates, who did not succeed in making anybody better (Athens inclusive). Democracy as a form of life is a chance for societies and individuals; not a chance for self-creation, for consciously created art-of-living, but for a certain shape of life dependent on the past. That is why every democracy is different.

Socrates did not make Athens better. Daimonion forbade him from it. Since the polis is rotten (even a blockhead can sue everyone), the work of improvement had to begin with individuals. Socrates was the only one who performed the statesman's task. But this task was in fact an event dependent on divine providence (theia moira), and not guaranteed by a method, an outcome. It is a paradox that rotten Athens was, for Socrates, the condition of possibility, and, at the same time, his element. Leaving Athens 
went beyond the horizon of Socrates' service and his self-understanding. Perhaps the figure of Socrates reveals two faces of democracy: one that is the field of "servants" who provide the polis's goods and endeavor to satisfy its citizens, where a certain instrumental method, knowledge and predictability of results are possible. And the second, which Socrates called the "improvement" of the citizens, where there was no object knowledge, nor could it exist; for, as we remember, he who is happy having reached his destination after a dangerous sea voyage does not know - and cannot know - whether it would have been better for him if he had drowned.

Plato deeply misunderstood the democracy outlined by the figure of Socrates and his practice of life as presented in the earlier dialogues. Nor did he understand the relations implied by the figure of Socrates between democracy, knowledge and aretai. The great nomoi speech in Crito perfectly renders Socrates' situation in the polis, but maybe Plato was simply a poet while writing the earlier dialogues. The enthusiasmos given to him by the gods made him form a different Socrates and a different concept of polis in those dialogues. Plato the philosopher left to us a complex project for the polis in his Republic, with guarantees that every generation would have a Socrates. Plato wanted to have a guarantee, to reduce the reality of the polis and politics to an efficient mechanism, that is, to achieve what Socrates thought impossible.

That is why I cannot agree with another outstanding critic of Plato, Myles F. Burnyeat who in his essay on Republic says: "the non-existence of the ideal city is a fact of history, not of metaphysics." Then he makes his statement more precise: "There are indeed metaphysical obstacles to the realization on earth of perfect justice. These are conceded by Socrates when he says that nothing can be realized in deed as it is spoken in word (473a)." And further: "Socrates and his interlocutors ... agree that the question whether the ideal city is a practicable possibility 
should be understood as the question whether a reasonable approximation to it is a practicable possibility (473a-b)." ${ }^{29}$

If the above argumentation concerning arete is correct, then a proposition opposite to Burnyeat's is true: the ideal Platonic polis does not exist, not because we have been unable to realize it in history thus far (even in some sensible approximation), due to social or political reasons, but because metaphysical reasons make its existence impossible. The praxis (not consciousness) of Socrates, the only true politician in Athens, points to metaphysical obstacles to educating the philosopher-king. The just polis does not exist not because - as Burnyeat sees it - there has never been a philosopher-king of such power and understanding capacity that are required to organize a society correctly. The metaphysical problem concerning the existence of such rulers derives from the fact that their existence is incompatible with any form of upbringing and education. This is the meaning of the concept of aretc implied in the earlier dialogues. The lack of knowledge and the basic non-instrumentality of the social life are not a deficiency that can be made up - they are inscribed in the mode of man's and the polis's existence.

The figure of Socrates is also a challenge: it is the ability to recognize "Socrates," as our fate depends on this recognition. But whether we recognize him depends on who we already are, that is, partly on the polis in which we live. Polis waits for Socrates, who sets off in the hope of meeting living arete every day.

Translated by Paulina Chołda

First edition: Sokrates - arete i demokracja, "Civitas. Studia z Filozofii Polityki" 2004, vol. 8, pp. 9-39.

\footnotetext{
${ }^{49}$ M.F. Burnyeat: Utopia and Fantasy: The Practicability of Plato's Ideally Just City, in: G. Fine (ed.), Plato 2. Ethics, Politics, Religion and the Soul, Oxford University Press, Oxford 1999, pp. 299-300.
} 